\title{
Homeland science chief wants quick fixes
}

Erika Check, Washington

In his first few weeks as undersecretary for science and technology at the US Department of Homeland Security, Charles McQueary has seen proposals for countless homeland-security devices, ideas for tamper-proof manhole covers and an antianthrax spray, among others. But so far he hasn't awarded so much as a cent to any of these pitches.

Although he was sworn in on 9 April, McQueary is still waiting for Congress to give him his first \$30 million, which he will spend on an initial round of grants to support the directorate's technology priorities. Until then, he is spending much of his time fielding queries from businesses, universities and inventors who want a share of the $\$ 800$ million that his directorate has requested from Congress for 2004.

The early signs are that bench scientists won't see much of the money. McQueary admits that his main priority will be to find existing devices and bring them rapidly into use. For the time being at least, the focus is on applied, rather than basic, science. "It's very important that we have an understanding about what kinds of scientific solutions exist today, so we can bring those to bear quickly," he says.

McQueary, a 63-year-old mechanical engineer, came out of retirement to head the new directorate. He spent much of his career running research and development programmes at defence contractor General Dynamics, and at AT\&T's Bell Laboratories in Murray Hill, New Jersey.

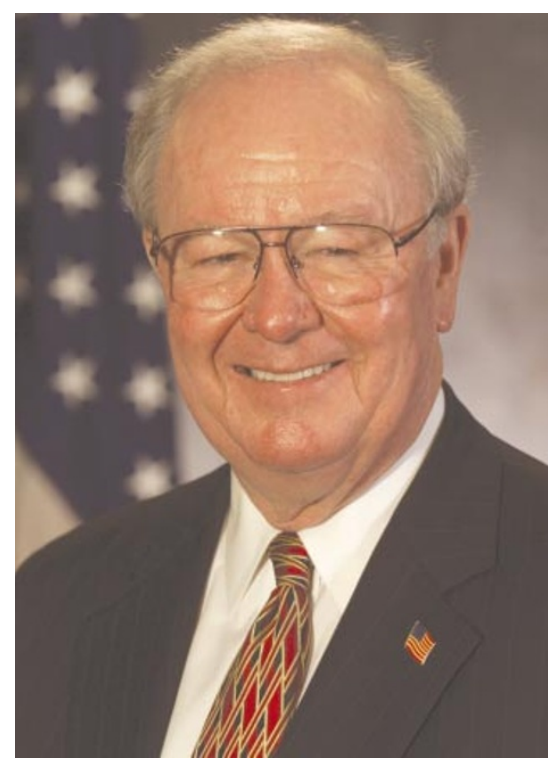

Charles McQueary: more interested in speedy solutions than in blue-sky research.

He is currently building up a staff of about 150 to run the science and technology directorate from the Department of Homeland Security's temporary headquarters, at a Navy complex in an opulent residential area of northwest Washington DC. The complex's wide, grassy lawns and red-brick buildings make it look like a university campus, but the number of officials strolling about in uniform - as well as the tight security at the front gate - give it the feel of a military base. The whole department is expected to move to new headquarters before too long.

Already, McQueary's actions are being watched assiduously by university officials, hopeful contractors and those in Congress who pushed in the first place for a Homeland Security directorate dedicated to science and technology. "We'd like to get more information from the administration on what kind of research agenda they intend to pursue and why," says David Goldston, chief of staff on the House Science Committee, which advocated setting up the directorate.

One part of that agenda that will be implemented this year, McQueary says, is the creation of university-based research centres in five priority areas: radiological, chemical, biological, nuclear and highexplosive threats.

The department will also organize its own Homeland Security Institute, probably led by staff at an existing federal institution such as the Lawrence Livermore National Laboratory in California. Next year, it is also expected to award $\$ 350$ million in new funding for critical areas such as border security, through a Homeland Security Advanced Research Projects Agency.

McQueary's focus on immediate solutions, rather than blue-sky ideas, may derive from the fact that he thinks about the terrorist attacks of 11 September almost every day. "It's easy to look back and say we could have done this or that, but the fact is we weren't thinking that way," McQueary says. "The challenge is to prevent the next thing that's comparable."

\section{Dying cells dragged screaming under the microscope}

Catherine Zandonella, New York

An eerie high-pitched song fills the air in a physics laboratory in Los Angeles. It is the

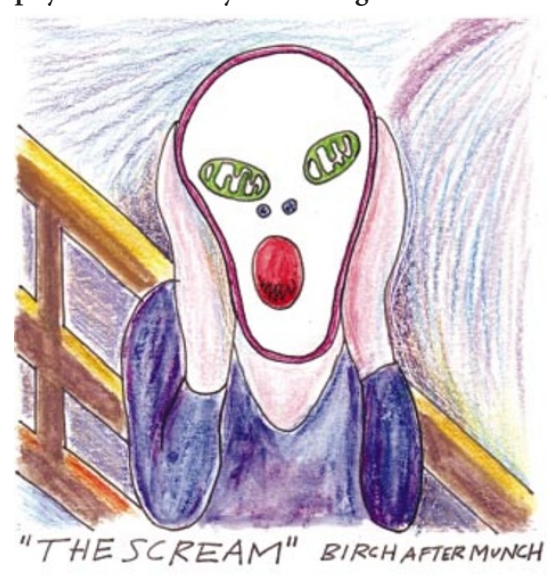

scream of a yeast cell as it withers in a pool of alcohol, and it just may proclaim a useful new technique for cell biologists.

The master of this cellular torture chamber is physical chemist James Gimzewski of the University of California, Los Angeles. Best known for his work on manipulating single molecules during his career at IBM's Zurich research laboratory, Gimzewski has of late turned his nanoknowhow towards exploring single cells. He is trying to develop a new technique for studying the cell by listening to the sound that its membrane makes.

Gimzewski and graduate student Andrew Pelling have been looking closely at how the outer membranes of yeast cells vibrate, depending on the condition of the cells. Now they're teaming up with cancer pathologist Michael Teitell of the UCLA
School of Medicine to establish whether this signature song could be used to monitor the health of a cell in response to both external stresses and internal ones, such as gene mutations.

To obtain such sensitive measures of the cell membrane, which moves only about two billionths of a metre with each vibration, Gimzewski and Pelling use the nanotechnologist's favourite tool - the atomic force microscope (AFM). The AFM's tip can be scanned over a surface to create a precise map of its topography. "We use the AFM as a type of stethoscope, to follow how cell membranes move," says Gimzewski, who has christened the method 'sonocytology'.

The researchers find that strains of yeast emit slightly different sound patterns. When amplified, they sound a bit like rhythmic 


\section{AIDS researchers seek criteria for vaccines}

\section{Erika Check, Washington}

Scientists have been seeking an AIDS vaccine for two decades now, with precious few signs of success. But while their search has focused primarily on a vaccine that would prevent the disease, some vaccine researchers have been looking for ways to augment existing drug treatments for AIDS.

Just as they find preliminary evidence that such a vaccine might work, however, researchers investigating such therapeutic vaccines are running into new difficulties.

Advocates of therapeutic vaccines complain, in particular, that regulators are stalling research in this field by refusing to set clear expectations for what such a vaccine needs to do. Without clear targets, scientists and companies say that they are reluctant to set up large, costly clinical trials.

But government officials counter that researchers are demanding too much guidance too soon - before they've even shown that such a vaccine could work. "I think there's been a hold-up on both sides," says Ben Cheng of the government-sponsored Forum for Collaborative HIV Research, which hosted a workshop on therapeutic vaccines in Washington DC on 23 and 24 April.

The idea behind therapeutic vaccines is to prolong the useful life of anti-retroviral therapies, which allow many patients to survive AIDS but are prone to failure over time, as the virus evolves resistance to the drugs. A few studies have hinted that a therapeutic vaccine could help to solve this problem by allowing patients to take short breaks from treatment.

In one such study, funded by the ANRS,

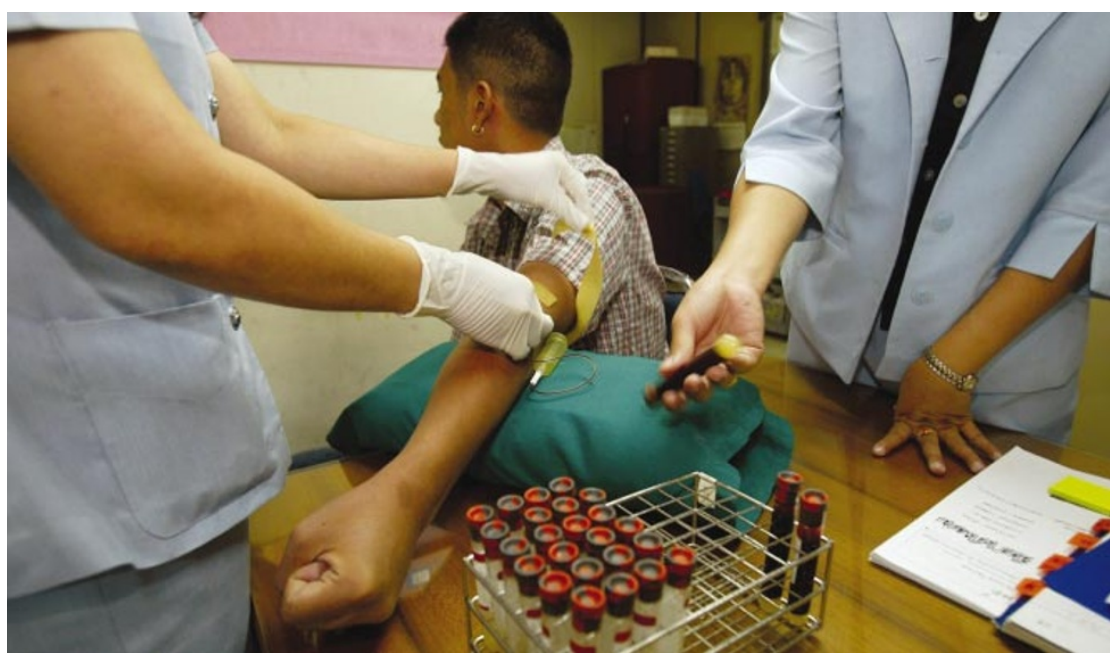

At the sharp end: researchers seek therapeutic vaccines to treat AIDS, as well as preventative ones.

the French national AIDS-research agency, Brigitte Autran and Christine Katlama of the Hôpital Pitié-Salpêtrière in Paris found that a canarypox vaccine let some patients take slightly longer breaks from drugs than others (see Nature 422, 650; 2003). And earlier this year, Yves Levy of the ANRS reported that patients who took a vaccine and a biological booster suppressed the virus better than those who did not take a vaccine.

The question now is what regulatory agencies will do with this evidence. A preventative AIDS vaccine succeeds when it stops people becoming infected with the virus. But a therapeutic vaccine's success could take many forms: reducing the number breathing. When researchers dribble some isopropyl alcohol onto one of the yeast cells, the pitch increases sharply, as if the cell is emitting a shrill cry. A dead cell produces the kind of static you might hear when tuning a radio.

Researchers have previously used an AFM to detect the pulsing surface of cardiac cells, which 'beat' even when removed from the body (S. G. Shroff, D. R. Saner and R. Lal, Am. J. Physiol. Cell Physiol. 269, C286-C292; 1995). But Gimzewski thinks that he's the first to listen to the membrane resonance of other cell types.

Gimzewski - a high-flyer at IBM who has published frequently in major scientific journals, including Nature - hasn't yet published anything on his idea. But he has discussed it with the LA Weekly, an alternative newspaper in Los Angeles, and he plans to demonstrate it this autumn at the Los Angeles County Museum of Art, in a nanotechnology exhibition held jointly with an artist with whom he has collaborated before, Victoria Vesna. He says that this approach fits in with his goal of taking science to a wider audience.

Sceptics point out that the technique may not work for mammalian cells, which have much softer membranes than yeast cells. But Jan Hoh, a physiologist at Johns Hopkins School of Medicine, says that he is intrigued by the concept of sonocytology. "If there are frequencies in the kilohertz range that truly are diagnostic to something going on in the cell, that would be interesting," says Hoh. He cautions that treating cells with alcohol is too crude to reveal much, however. of HIV particles in a patient's body, for example, or allowing the patient to stay off drugs for a certain period of time.

So far, the US Food and Drug Administration (FDA) and other agencies have not told scientists which of these criteria it will consider as proof of success. But at the workshop, Carol Weiss, a scientist at the FDA's Office of Vaccines Research and Review, gave some indications. "The treatment needs to change a patient's outcome in a clinically meaningful way," Weiss said, adding that the change must be "durable". How durable, she said, has not yet been determined, but she hinted that any approved vaccine would have to work for at least six months. Weiss also said that an FDA advisory committee would probably have to approve the first large trial of any therapeutic vaccine.

That statement will not satisfy everyone. But Dan Kuritzkes, director of AIDS research at the Partners AIDS Research Center at Massachusetts General Hospital, says that the FDA's comments will help scientists. "I think we came out with a much clearer sense of what the potential indications might be for therapeutic vaccines," such as a lower viral load or an extended time off treatment, Kuritzkes says. He adds that this is especially important for commercial vaccine development: "Industry needs to have a sense that if they get to the end of the road, the agencies will have similar expectations about what is reasonable."

Alan Landay, an immunologist at RushPresbyterian-St Luke's Medical Center in Chicago, says that the workshop marked a milestone for therapeutic vaccines in at least one sense: by the end of it, much of the tension between regulators and scientists had dissipated. "Everyone in the room saw that others were facing the same sorts of questions they had," Landay says. "Now we all know we're not alone in this quest." 